\title{
ASSESSMENT OF INDICATORS OF FACULTY MASS SPORT FUNCTIONING IN HIGER EDUCATIONAL ESTABLISHMENT
}

\author{
Kirpenko V.N.
}

Kharkov Air Force University Kozhedub

\begin{abstract}
Purpose: to work out the methodic of determination of military higher educational establishment faculty's rating for improvement of organization, monitoring and control of physical education process at the faculty. Material: we used systemic-structural analysis; functioning of military higher educational establishment faculty was simulated; quantitative values of faculty functioning integral rating, connected with organization and conducting of sport measures, were obtained. Results: on the base of hierarchic model of faculty functioning we offered model of faculty rating. Decomposition of its structure was carried out up to the level, at which it is possible to make objective quantitative assessments of separate kinds of functioning. Conclusions: the worked out rating-model of functioning results shows functional connection of faculty's integral rating with its special ratings as well as connections between different kinds of functioning at different levels of de-composition. We found clear connection of special ratings of lower level with quantitative assessments of functioning. It permits to differentially approach to comparison and assessment of faculty's functioning.
\end{abstract}

Key words: rating, model, functioning, integral, primary, assessments.

\section{Introduction}

As on to day, testing and assessment of military higher educational establishment (MHEE) faculty is a certain system, one of elements of which is assessment of physical training's organization and conduct (Methodic of complex testing (current, partial) of situation in military higher educational establishments and military educational units of higher educational establishments. Approved by Order of Ministry of defense of Ukraine, dt. 08.09.2014 № 630. Order of Ministry of defense of Ukraine, dt. 19.02.2015 № 49 “On organization of physical training in Armed Forces of Ukraine in 2015 academic year") [8-12, 13-19]. Reviews of mass sport work (RMSW) is one of those testing, which can be used as mean for assessment of faculty's functioning on organization and realization of physical trainings. However, the existing system of results' assessment strongly differs by conditions of RMSW in Armed Forces of Ukraine (AF of Ukraine) from system, which existed in period 1945 - 1990. It does not permit to completely use differentiated approach to assessment of functioning results of faculties, which prepare specialists of different military profiles [3, 7].

Analysis of recent publications witnesses that characteristic feature of modern state of Ukrainian AF reformation is transition to optimization of their structure and quantity, bringing them in compliance with economic potentials of the State. In HEEs of MD of Ukraine there appears an acute demand in searching the ways and means of comparison and assessment, activation of all kinds of faculties' functioning, including functioning, connected with organization and realization of mass sport measures $[1,3,7]$. It should be noted that assessment of faculties' mass sport functioning was always conducted. But only recent years rating system of assessment have been started to be discussed. It is explained by the fact that rating system is more perfect, comparing with earlier existing system (Report about SRW "Module" "Methodological principles of module rating system of pedagogic process organization" // МОУ НМЦ ВО. - К., 2001. -77 c.) $[4,5]$.

Purpose, tasks of the work, material and methods

The purpose of the research is to determine indicators of faculty's functioning in mass sport work, to assess them and work out rating-model for mass sport and sport work at MHEE faculty.

\section{Results of the research}

It is purposeful to adopt the methodic of construction of rating model of faculty functioning results on all levels of de-composition in the form, which was developed when construction rating models of MHEEs of Ukraine (Report about SRW "Module" "Methodological principles of module rating system of pedagogic process organization" // MOY НМЦ ВО. - К., 2001. - 77 c.). The model of mass sport and sport functioning of MHEE is shown in fig. 1.

The model of organization and realization of sport mass and sport work includes three main kinds of faculty's military officers' functioning $[10,15]$.

First kind "5.1. Mass sport work" stipulates training of faculty military officers and their participation in mass sport measures, conducted in HEE and out of it. They include:

- Faculty's participation in championships (full time and correspondence) among MHEEs of Ukraine;

- Faculty's participation in MHEE championship;

- Faculty's participation in regional championships among MHEEs. 


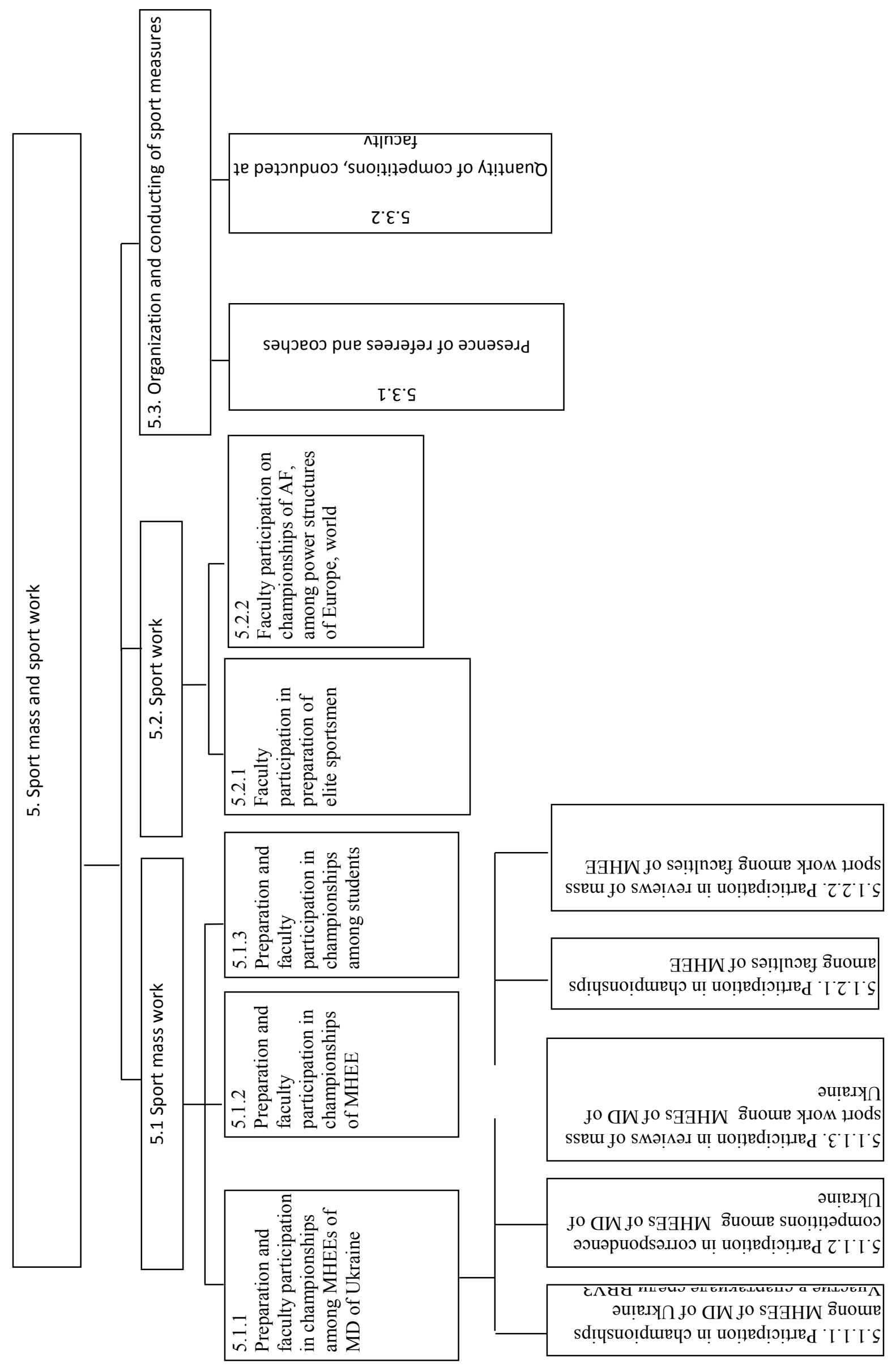




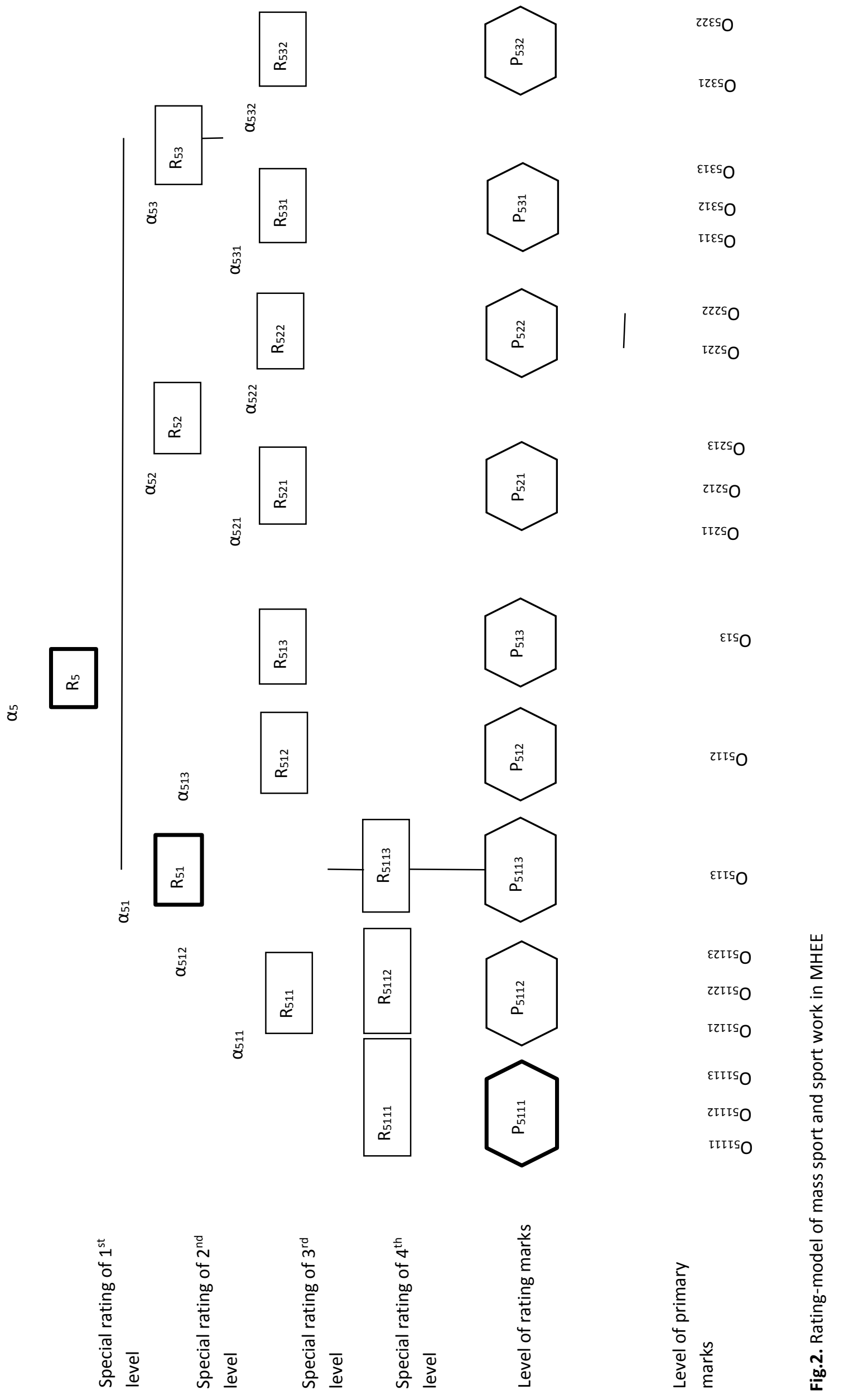


Second kind "5.2. Sport work" determines level of all faculty military officers' personal readiness for passing normative, sport grades and other sport qualification requirements (candidate master of sports, master of sport and so on) as well as participation in competitions of Armed Forces of Ukraine level and higher.

Third kind "5.3. Organization and conducting of sport measures" specifies qualification level of those, who organize and conduct sport measures as well as quantitative indicators of organized and conducted sport measures on faculty.

According to model of faculty functioning adequate to it rating-model has been built (see fig.2).

As the base of faculty rating in organization and conducting of mass sport measures we applied approaches, used in military qualimetry and mathematical statistic [5,6]. It is offered to insert some additions in them, which will permit to consider in assessment the following:

- Sport achievements of combined teams of MHEE in proportion to quantity of representatives from faculty in them;

- place, taken by MHEE team in championship among MHEEs of Ukraine as well as faculty work on preparation of qualified referees, coaches and conducting of competitions on faculty. Let us regard formation of marks by main kinds of faculty functioning.

Functioning kind 5.1.1 was assessed by faculty participation in championship and in correspondence competitions among MEEs of Ukraine, by participation in "Review for the best organization of physical training and mass sport work in AD of Ukraine".

Kinds of functioning 5.1.1.1 и 5.1.1.2 were assessed by participation of every faculty in team of kinds of sports, which are envisaged by program of championship and correspondence competitions. By results of MHEEs' combined teams' performances in assessment of faculty it is necessary to consider the staff of combined team, determined by total quantity of team $\left(K_{\mathrm{o}}\right)$ and by quantity of faculty representatives in this team $\left(K_{f}\right)$ as well as the place, taken by MHEE combined team in championship or at correspondence competitions $(D)$. Primary marks of every component for kind of functioning 5.1.1.1 are calculated by formula:

$$
O_{f i}=\frac{K_{f i}}{K_{o i} \times D_{i}}
$$

$K_{o i}$ and $K_{f i}$, are not constant values and can not be predicted. They depend on number $(i)$ of MHEEs' combined teams, which took certain place in competitions. Ordeal number of team changes within the limits $0 \leq i \leq N$ (where $N$ is quantity of kinds of sports by program of championship and correspondence competitions). Rating mark shall consider achievements of all sport teams, which participate in competitions of kinds 5.1.1.1. and 5.1.1.2.

In the same way marks for other kinds of functioning 5.1.1.2 are determined.

The only difference is that $D$ (place of our university in correspondence competitions) for all faculties will be one and the same; that is why it is not considered in the formula.

In functioning kind 5.1.1.3 results of mass sport work review within the frames of our university are considered and have only one component of primary mark. Primary mark of this component is determined by place of faculty in the university as per conditions about conduct of "Review for the best organization of physical trainings and mass sport work in AF of Ukraine". Then, rating mark will coincide with primary mark, i.e. $P_{5113}=O_{5113}$.

$$
\begin{aligned}
P_{5113}=\frac{D_{f}}{\sum_{i=1}^{N} D_{i}} & R_{5111}=\frac{P_{5111}}{\sum_{i=1}^{N}\left(P_{5111}\right)_{i}} \\
P_{5111}=\sum_{i=1}^{N} \frac{K_{f i}}{K_{o i} \times D_{i}} & R_{5113}=\frac{P_{5113}}{\sum_{i=1}^{N}\left(P_{5113}\right)_{i}}
\end{aligned}
$$

Special rating of faculty by kind of functioning 5.1.1 is calculated by formula:

$$
R_{511}=\alpha_{111} R_{5111}+\alpha_{112} R_{5112}+\alpha_{113} R_{5113}
$$


Primary mark $O_{5121}$ of functioning kind 5.1.2 is determined by results of faculty participation in every kind of sports, envisaged by MHEEs' championship program. For calculation of the mentioned primary marks the following expression is used:

$$
O_{5121}=1-\frac{n}{N}
$$

Where $n$ is the place, taken by faculty in certain kind of sports at championship;

$N$ is the sum of faculties places in this kind of sports (faculties, participating in championship).

Rating mark is calculated by formula:

$$
P_{5121}=\sum_{i=1}^{N}\left(O_{5121}\right)_{i}
$$

In functioning kind 5.1.2.2 results of mass sport work review within the frames of our university are considered and have only one component of primary mark. In functioning kind 5.1.1.3 results of mass sport work review within the frames of our university are considered and have only one component of primary mark. Primary mark of this component is determined by place of faculty in the university as per conditions about conduct of "Review for the best organization of physical trainings and mass sport work in KhUAF”.

Faculty sport work (kind of functioning 5.2) is assessed by quantity of faculty military officers, who confirmed or passed sport normative and qualification requirements during academic year as well as took proper places at competitions of Armed Forces and MHEEs. The procedure of scoring for fulfillment of sport normative (international master of sports, master of sports, candidate master of sports, first, second, third grades) and for places, won at competitions was determined by appropriated rules.

Faculty work on organization and conducting of sport measures was assessed by place of faculty by quantity of faculty military officers, having qualification of referee of International, National, first and second categories, coaches. The procedure of scoring for qualification level was determined by appropriated rules.

Total faculty rating is calculated by formula:

$$
R_{5}=\alpha_{1} R_{51}+\alpha_{2} R_{52}+\alpha_{3} R_{53}
$$

Finally, it would be purposeful to render the values of weight coefficients $\alpha$ (see table 1), which are recommended to be used when determining faculty rating on mass sport and sport work. They were received on the base of generalization of many years' experience of physical education, special physical training and sport department as well as experience of sport committee of Kharkov university of Air Forces in assessment of mass sport and sport work at the university. The rendered data are not final; they can be specified.

Table 1. Recommended numerical values of weight coefficients $\alpha$

\begin{tabular}{lllllllll}
\hline Description & $\boldsymbol{\alpha}_{51}$ & $\boldsymbol{\alpha}_{52}$ & $\boldsymbol{\alpha}_{53}$ & $\boldsymbol{\alpha}_{511}$ & $\boldsymbol{\alpha}_{512}$ & $\boldsymbol{\alpha}_{513}$ & $\boldsymbol{\alpha}_{521}$ & $\boldsymbol{\alpha}_{522}$ \\
\hline Numerical value & 0,6 & 0,3 & 0,1 & 0,25 & 0,3 & 0,45 & 0,45 & 0,55 \\
Description & $\alpha_{531}$ & $\alpha_{532}$ & $\alpha_{5111}$ & $\alpha_{5112}$ & $\alpha_{5113}$ & $\alpha_{5121}$ & $\alpha_{5122}$ & - \\
Numerical value & 0,7 & 0,3 & 0,25 & 0,3 & 0,45 & 0,4 & 0,6 & - \\
\hline
\end{tabular}

\section{Discussion}

The content of functions and kinds of faculty activities, methods of their accounting and assessment are determined by normative documents, regulating separate directions of armed forces' functioning [9-12].

For improvement of military officers' physical fitness, development of mass sport, organization of meaningful leisure of personnel at faculty mass sport and sport work are organized [Order of Minister of defense, dt. 19.02.2015 № 49 "On organization of physical training in Armed Forces of Ukraine in 2015 academic year"]. It is known that organization level and content of mass sport and sport work on faculty directly influence on effectiveness of cadets' functioning and quality of graduates. That is why traditional approach to assessment of results of this work can not permit to objectively assess and compare faculties, which prepare specialists of different profiles. In earlier offered assessment methods quantity of indicators for objective assessment of MSW* is not sufficient. For example, in work [7] it is noted that MSW results are assessed by data, rendered by units' commanders. Methods of conducting and assessment of MSW do not differ noticeably. Difference in results is explained by authors by different approaches to planning.

*MSW - mass sport work (note of translator). 
However, the results, received by us, show that rating system of assessment plays rather important role. This system has been worked out and substantiated on the base of model of faculty functioning. De-composition of its structure is carried out up to the level, at which it is possible to realize objective quantitative assessment of separate kinds of functioning. We determined required mathematical correlations, permitting to express integral rating of faculty though special ratings by separate kinds of functioning as well as to express special ratings through assessment of these kinds of functioning. List of initial data and mechanism of their re-calculation in primary marks of faculty kinds of functioning do not require additional researches of rating object.

\section{Conclusions}

On the base of the worked out model of functioning we have offered rating-model, permitting to objectively assess and compare functioning of faculties in MSW.

We have found the list of initial data and mechanism of their re-calculation in primary marks of faculty functioning. These data can be inserted in data base of automatic system of faculty rating's determination.

The offered in this work model of MHEE mass sport and sport work can be regarded as variant. The model undoubtedly requires discussion and specifying by physical training and sports departments of all MHEEs of Ukraine.

\section{Conflict of interests}

The authors declare that there is no conflict of interests.

\section{References:}

1. Barybina LN, Semashko SA, Krivencova EV. Osobennosti organizacii sportivno-massovoj raboty v tekhnicheskom vuze [Specific features of porganization of mass sport work in technical HEE]. Physical education of students, 2011;1:18-21.

2. Kirpenko VM, Piddubnij OG, Bozhko SA. Ocinka efektivnosti iakosti pidgotovki kursantiv z disciplini «Fizichne vikhovannia, special'na fizichna pidgotovka i sport» [Assessment of effectiveness of cadets' training in discipline" physical education, special physical training and sports"]. Pedagogics, psychology, medical-biological problems of physical training and sports, 2008;12:14-18. (in Ukrainian)

3. Kirpenko VM. Pidvishchennia efektivnosti pedagogichnogo procesu special'noi fizichnoi pidgotovki kursantiv VVNZ povitrianikh sil na osnovi idei optimizacii [Increase of effectiveness of pedagogic process of special physical training of Air Forces' MHEEs cadets, considering optimization]. Slobozhans'kij naukovo-sportivnij visnik, 2013;2:169-174. (in Ukrainian)

4. Liamec VI, Teviashev AD. Sistemnyj analiz [Systemic analysis]. Kharkov: KhTURE; 1998. (in Russian)

5. Oleksiienko BM. Teoretichni osnovi vijs'kovoi kvalimetrii [Teoretichni osnovi vijs'kovoi kvalimetrii]. Hmelnitsky; 2000. (in Ukrainian)

6. Sidorenko EV. Metody matematicheskoj obrabotki $v$ psikhologii [Methods of mathematical processing in psychology]. Sankt Petersburg: Socio-Psychological Center; 1996. (in Russian)

7. Sukhorada GI. Sportivno-masova robota u vishchikh vijs'kovikh navchal'nikh zakladakh. Cand. Diss. [Mass sport work in military higher educational establishments. Cand. Diss.]. Kiev; 2003. (in Ukrainian)

8. Army Regulation 350-1, Army Training and Leader Development. Washington, DC: Headquarters, Department of the Army, 18 December 2009; Section VI, “Army Training Programs", 1-24. "Army physical fitness training"; 2009.

9. Army Regulation 40-501 Standards of Medical Fitness. Washington, DC: Headquarters, Department of the Army, 14 December; 2007.

10. Canadian Forces, Expres Operations Manual (4-th Edition); 2010.

11. Field Manual FM 7-22 Army Physical Readiness Training with Change 13 May 2013 Paperback. by United States Government US Army; 2013.

12. Joseph E. Raycroft Mass Physical Training: For Use in the Army and the Reserve Officers Training Corps Forgotten Books; 2015.

13. McGraw LK, Out D, Hammermeister JJ, Ohlson CJ, Pickering MA, Granger DA. Nature, correlates, and consequences of stress-related biological reactivity and regulation in Army nurses during combat casualty simulation. Psychoneuroendocrinology. 2013;38(1):135-144.

14. McGeachan C. Needles, picks and an intern named Laing: exploring the psychiatric spaces of Army life. Journal of Historical Geography. 2013;40:67-78.

15. Lewandowski-Romps L, Peterson C, Berglund PA, Collins S, Cox K, Hauret K, et al. Risk Factors for Accident Death in the U.S. Army, 2004-2009. American Journal of Preventive Medicine. 2014;47(6):745-753.

16. Walker D, Neighbors C, Walton T, Pierce A, Mbilinyi L, Kaysen D, et al. Spicing up the military: Use and effects of synthetic cannabis in substance abusing army personnel. Addictive Behaviors. 2014;39(7):1139-44.

17. Portman N, Šlapeta J. The flagellar contribution to the apical complex: a new tool for the eukaryotic Swiss Army knife? Trends in Parasitology. 2014;30(2):58-64. 
18. Raiha NK, Soma DJ. Victims of child abuse and neglect in the U.S. army. Child Abuse \& Neglect. 1997;21(8):759768.

19. Smith TJ, Sigrist LD, Bathalon GP, McGraw S, Karl JP, Young AJ. Efficacy of a Meal-Replacement Program for Promoting Blood Lipid Changes and Weight and Body Fat Loss in US Army Soldiers. Journal of the American Dietetic Association. 2010;110(2):268-273.

\begin{tabular}{|l}
\hline \multicolumn{3}{|c|}{ Information about the author: } \\
Kirpenko $\quad$ V.N.; http://orcid.org/0000-0003-3682-7352; \\
wital73@mail.ru; Kharkov Air Force University Kozhedub; \\
Street. 77/75 Sumy, Kharkov, 61000,, Ukraine.
\end{tabular}
Street. 77/75 Sumy, Kharkov, 61000,, Ukraine.

Cite this article as: Kirpenko V.N. Assessment of indicators of faculty mass sport functioning in higer educational establishment. Physical education of students, 2015;5:16-22. http://dx.doi.org/10.15561/20755279.2015.0503

The electronic version of this article is the complete one and can be found online at: http://www.sportpedu.org.ua/html/arhive-e.html

This is an Open Access article distributed under the terms of the Creative Commons Attribution License, which permits unrestricted use, distribution, and reproduction in any medium, provided the original work is properly cited (http://creativecommons.org/licenses/by/4.0/deed.en).

Received: 16.08.2015

Accepted: 29.08.2015; Published: 02.09.2015 